\title{
MANAJEMEN PENGELOLAAN WAKAF TANAH MASJID JAMI' DARUSSALAM DESA JATIPAYAK KECAMATAN MODO KABUPATEN LAMONGAN UNTUK MENINGKATKAN PEREKONOMIAN MASYARAKAT
}

\author{
Devi Agustina ${ }^{1}$ \& Renny Oktafia ${ }^{2}$ \\ ${ }^{1 \& 2}$ Perbankan Syariah, Fakultas Agama Islam, Universitas Muhammadiyah Sidoarjo \\ Email:deviagustina485@gmail.com,renny.oktafia@umsida.ac.id
}

\begin{abstract}
ABSTRAK
Masjid Jami' Darussalam memberikan peluang kepada masyarakat untuk memanfaatkan tanah wakaf yang dimiliki masjid yang berupa tanah sawah yang disewakan kepada masyarakat untuk menambah perekonominan. Penelitian ini bertujuan untuk mengetahui bagaimana manajemen pengelolaan wakaf tanah masjid dan dampak dari pengelolaan wakaf tanah masjid di Desa Jatipayak dengan menggunakan indikator maqashid syariah pada konsep peningkatan perekonomian masyarakat. Hasil penelitian ini menunjukkan bahwa manajemen pengelolaan wakaf tanah tersebut belum maksimal karena pada manajemen pengembangan tanah wakaf yang berupa sawah digunakan untuk sewa saja dibidang pertanian dan manajemen pemanfaatan masih konsumtif yang digunakan untuk kepentingan masjid dan masyarakat sekitar serta pada manjemen pelaporan yang masih belum dilaksanakan sesuai aturan akan tetapi dari segi peningkatan perekonomian masyarakat penyewaan tanah wakaf yang dilakukan oleh masjid tersebut dapat meningkatkan perekonomian masyarakat dari indikator agama, jiwa, akal, keturunan dan harta.
\end{abstract}

Kata Kunci: Manajemen, Wakaf, Peningkatan Perekonomian, Maqashid.

\begin{abstract}
Jami' Darussalam Mosque provides an opportunity for the community to take advantage of the waqf land owned by the mosque in the form of rice fields that are rented out to the community to increase the economy. This study aims to find out how the management of mosque land waqf management and the impact of mosque land waqf management in Jatipayak Village by using sharia maqashid indicators on the concept of improving the community's economy. The results of this study indicate that the management of land waqf management is not optimal because the management of waqf land development in the form of rice fields is used for rent only in agriculture and consumptive utilization management which is used for the benefit of mosques and the surrounding community as well as reporting management which has not been implemented according to the rules. However, in terms of increasing the community's economy, the rental of waqf land carried out by the mosque can improve the community's economy from the indicators of religion, soul, mind, lineage and property.
\end{abstract}

Keywords: Management, Waqf, Economic Improvement, Maqhasid. 


\section{PENDAHULUAN}

Wakaf di Indonesia berkembang dengan pesat tidak hanya kuantitasnya saja tetapi juga jenis harta benda wakaf, salah satunya wakaf tanah berupa lahan sawah, di dalam pengelolaan lahan sawah tersebut menggunakan sistem sewa menyewa yang dilaksanakan oleh nadzir dengan penyewa lahan sawah yaitu masyarakat sekitar. Dengan menyewakan lahan sawah tersebut mengurangi resiko menganggurnya tanah wakaf agar menjadi tanah wakaf produktif yang dapat memberikan manfaat bagi masyarakat sekitar dengan meningkatnya perekonomian masyarakat.

Wakaf terdahulu dilaksanakan sesuai dengan kepahaman masyarakat, yaitu hanya dilaksanakan secara lisan sebelum adanya undang-undang yang mengatur dengan dasar wakif dan nadzir saling mempercayai bahwasannya urusan wakaf tidak ada yang berani menganggu karena berurusan langsung dengan Allah SWT (Rahman, 2019). Akan tetapi masih banyak banyak terjadi sengketa wakaf dikarenakan pengelolaan wakaf masih konsumtif dan tradisional oleh karena itu pemerintah mengeluarkan Undang-undang Nomor 41 Tahun 2004 Tentang Wakaf (Huda et al, 2018). Dalam Undang- undang Nomor 41 Tahun 2004 tentang wakaf, yang isinya pengelolaan dan pengembangan harta benda wakaf dilakukan secara produktif (Komaruddin et al, 2020). Pengesahan undang-undang dilaksanakan untuk memajukan kesejahteraan umum dari sini regulasi kesejahteraan umum sangat berpengaruh dalam hal perwakafan yaitu untuk kesejahteraan umat manusia pada bidang pendidikan, ekonomi, kesehatan maupun bidang-bidang lainnya (Rozalinda,
2012). Adapun landasan dasar hukum wakaf yang tertera dalam surah $\mathrm{Al}$ Imran ayat 92 :

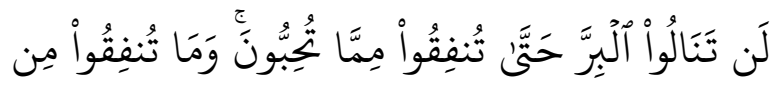

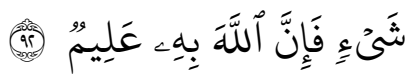

Artinya: Kamu tidak akan memperoleh kebajikan, sebelum kamu menginfakkan sebagian harta yang kamu cintai. Dan apa pun yang kamu infakkan, tentang hal itu sungguh, Allah Maha Mengetahui (Q.S. AlImran ayat 92).

Ayat di atas menjelaskan bahwasanya seseorang tidak mencapai kebajikannya disisi Allah SWT sebelum mengikhlaskan harta yang dicintainya dengan menafkahkanya dijalan Allah SWT (Hasan \& Rajafi, 2018). Dalam Islam wakaf sudah dikenal sejak zaman Rasulullah SAW Menurut pendapat para ulama wakaf dilaksanakan pertama kali oleh Nabi Muhammad SAW adalah dengan wakaf tanah yang digunakan untuk membangun masjid di Madinah hingga saat ini masih diterapkan masyarakat Islam (Huda \& Fauzi, 2019).

Pertanian merupakan salah satu solusi digunakan untuk mengurangi resiko menganggurnya tanah wakaf, di Indonesia juga mayoritas warga negaranya sebagai petani, akan tetapi sekarang sudah mulai berkurang dikarenakan adanya konferensi lahan pertanian menjadi non pertanian (Muqorobin \& Agustiyani, 2017). Pada data Badan Wakaf Indonesia yang menyatakan bahwa beberapa luas tanah wakaf yang bersertifikat, berikut data tanah wakaf yang bersertifikat di Indonesia pada tahun 2019 dari Badan Wakaf Indonesia. 
Gambar 1. Data Tanah Wakaf di Indonesia dan Jawa Timur

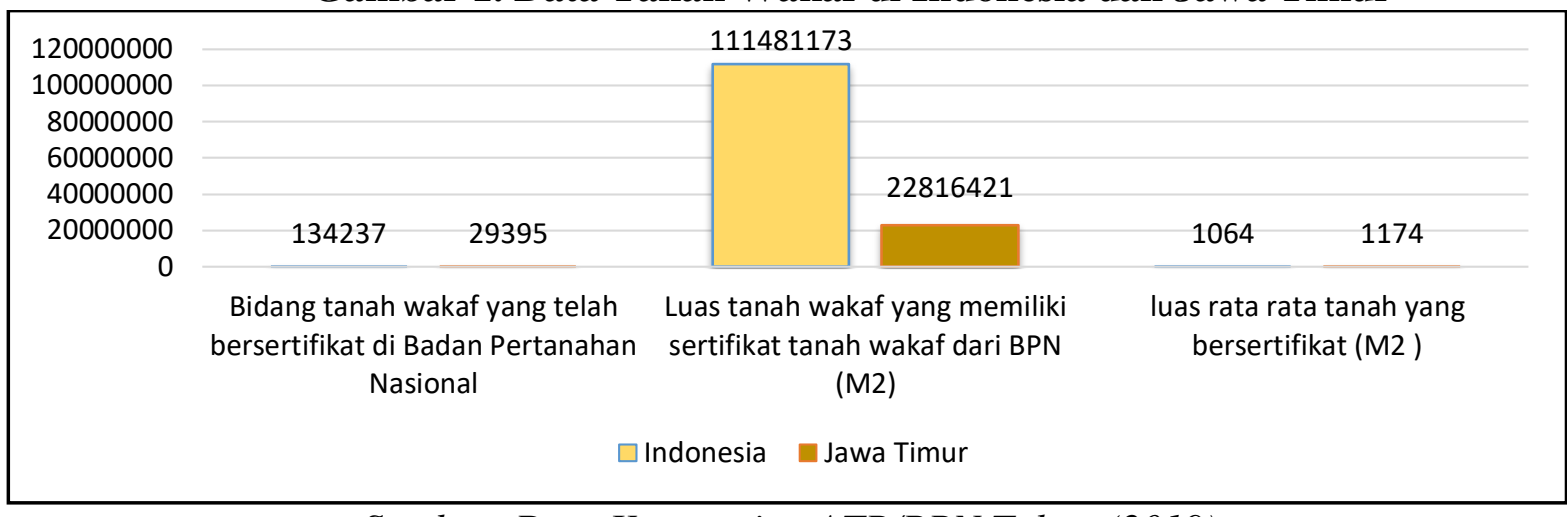

Sumber: Data Kementrian ATR/BPN Tahun (2019)

Dari data di atas menunjukkan bahwa banyak wakaf tanah yang dilaksanakan untuk meminimalisir terjadi menganggurnya tanah, maka bisa digunakan dalam bidang pertanian yang dimana dapat meningkatkan kesejahteraan petani, besarnya potensi tanah wakaf ini dapat dimanfaatkan dengan baik sehingga dapat mewujudkan tujuan ekonomi Islam, yaitu mewujudkan pertumbuhan ekonomi jangka panjang mencapai kesejahteraan umat (falah) (Rahman \& Widiastuti, 2020). Sebagaimana Pengelolaan wakaf tanah yang diterapkan oleh Ponpes Gontor yang tidak hanya menerima wakaf dari pemerintah ataupun lembaga namun menyeluruh dari masyarakat sehingga wakaf dapat berkembang secara baik dengan ditujukkan dengan asset yang terus berkembang sehingga dapat diperuntukan untuk kepentingan civitas akademik dan masyarakat sekitar. (Oktafia et al, 2020)

Manajemen dalam pengelolaan seperti perencanaan, pengorganisasian, pelaksanaan dan pengawasan. Pengelolaan wakaf tidak dipisahkan oleh nadzir, disini nadzir yang menentukan berkembang atau tidaknya suatu wakaf tanah (Komarudin et.al, 2020). Pengelolaan harta wakaf yang bertujuan untuk memberdayakan masyarakat harus dilaksanakan terus menerus, tidak hanya untuk memakmurkan masyarakat saja akan tetapi sebagai wujud rasa syukur dan mengikuti jejak Rasululllah SAW (Hasanah, 2020).

Agar tidak terjadi permasalahan dalam pengelolaan wakaf maka pemerintah mengeluarkan peraturan perwakafan yakni Peraturan Pemerintah No. 28 Tahun 1997 tentang perwakafan tanah milik, dengan adanya Peraturan Pemerintah ini memberikan informasi lebih lanjut mengenai tanah wakaf dengan jelas (Darwanto, 2012).

Desa Jatipayak Kecamatan Modo, Kabupaten Lamongan memiliki masjid Jami' Darussalam yang mana memiliki asset tanah wakaf berupa tanah persawahan. Berdasarkan survei yang dilakukan oleh peneliti terhadap nadzir di masjid Jami' Darussalam yang mengelola harta wakaf, diketahui ada dua orang wakif yaitu Bapak Munif (bekas yayasan) dan Mbah Sarinten, dengan jumlah tanah pertanian berupah sawah seluas $3.480 \mathrm{~m}^{2}$ dan $6.420 \mathrm{~m}^{2}$ jadi luas keseluruhan adalah $9.900 \mathrm{~m}^{2}$. Tanah tersebut terbagi menjadi 9 petak sawah ditempat yang berbeda, pengelolan wakaf dilakukan bersama dengan masyarakat desa melaui sewa menyewa, nadzir menyewakan tanah sawah tersebut kepada masyarakat agar tanah tersebut menjadi tanah produktif, uang dari hasil sewa menyewa tersebut digunakan untuk kesejahteraan masjid. 
Pada penelitian ini manajemen pengelolaan menempati posisi teratas dan paling urgen dalam mengelola harta wakaf karena wakaf itu bermanfaat atau tidak, berkembang atau tidak, tergantung pada pola pengelolaannya. Pengelolaan wakaf yang ada sekarang, banyak sekali kita temukan wakaf tidak berkembang bahkan cenderung menjadi beban pengelolaan atau malah tidak terurus.

Tanah yang menjadi milik masjid Jami' Darussalam adalah tanah yang berupa tanah persawahan sekarang dimanfaatkan masyarakat sekitar digunanakan untuk bercocok tanam atau kegiatan pertanian. Tanah yang notabenenya termasuk tanah wakaf tersebut dimanfaatkan secara produktif yang hasilnya digunakan untuk memakmurkan masyarakat sekitar dan juga masjid.

\section{TINJAUAN PUSTAKA}

\section{Pengertian Wakaf}

Wakaf atau waqf secara bahasa artinya berhenti, menahan atau diam, sedangkan dalam istilah wakaf adalah asset yang dialokasikan untuk kemanfaatan umat yang dimana manfaatnya boleh dinikmati untuk kepentingan umum (Nurma, 2013). Dalam Islam wakaf merupakan menahan harta dan manfaatnya yang diberikan dijalan Allah SWT, memindahkan hak miliki pribadi menjadi hak milik badan agar memberi manfaat kepada umat dengan tujuan kebaikan dan keridhoan dari Allah SWT, jadi dapat disimpulkan bahwa wakaf adalah sedekah jariah yakni sumbangan amal kebaikan yang akan tetap mengalir meskipun sudah meninggal (Rahman \& Widiastuti, 2020). Wakaf sendiri merupakan benda yang diwakafkan agar bermanfaat, bisa dengan disewakan atau digunakan untuk hal-hal yang lebih maslahat, bermanfaat bagi orang banyak, hasil dari pengembangan wakaf itu bisa dialokasikan seperti kebutuhan sosial seperti rumah sakit atau ketempat pendidikan atau ke masyarakat secara meluas (Latifah et al, 2021)

Perkembangan wakaf di Indonesia sangat pesat dan banyak lembaga wakaf yang berdiri contohnya pada wakaf yang diperhatikan oleh yayasan Arwaniyah kudus sebagai berikut (Fahri \& Zaki, 2018):

1. Yayasan Arwaniyah menggalang dari masyarakat sekitar dan jamaah, asset yang dimiliki oleh yayasan Arwaniyah dimanfaatkan dalam tiga bidang yaitu agama, pendidikan dan sosial ekonomi. Dalam bidang agama di berdirikan masjid sebagai sarana ibadah oleh jamaah atau masyarakat setempat, sedangakan dalam bidang pendidikan didirikan madrasah dan pesantren tahfidz. Dalam bidang sosial ekonomi dibangun pabrik air mineral, kantor dan ruko.

2. Tanah wakaf yang dikelola oleh yayasan Arwaniyah menjadi asset produktif untuk mengembangkan unit-unit usaha seperti pembuatan pabrik air mineral, percetakan dan ruko telah dikelola dengan baik sehingga dapat membua lapangan kerja baru.

Tidak hanya di Yayasan Arwaniyah Kudus sebagaimana dalam pengolalan wakaf Pondok Pesantren Darussalam Gontor dalam pengelolaan wakafnya sudah memiliki lebih dari 31 unit usaha dari berbagai sektor seperti perdagangan, perindutrian dan usaha layanan jasa, wakaf di Gontor sendiri pemanfaatnya sesuai dengan kebutuhan pondok pesantren sendiri dan masyarakat sekitar (Masruchin, 2019).

\section{Manajemen Dan Pengelolaan Wakaf}

Manajemen berasal dari kata manage yang artinya kontrol, sedangkan dalam bahasa Indonesia adalah mengendalikan, menangani atau mengelola, jadi manajemen adalah suatu proses yang terdiri dari perencanaan, pengorganisasian, pelaksanaan dan pengawasan yang dilakukan untuk mencapai tujuan yang ditetapkan dengan melibatkan fungsi-fungsi utama manajemen (Mustofa et al, 2020).

Untuk mendapatkan wakaf produktif maka nadzir harus mengerti prinsip-prinsip manajemen sebagai berikut (Assegaf \& Mursyid, 2020) : 
1. Tahapan fungsi manajemen yang meliputi aspek perencanaan, pengorganisasian, pengarahan dan pengawasan.

2. Manajemen fundraising atau penyusunan strategi dan rencana program kerja dalam wakaf produktif.

3. Manajemen pengembangan, manajemen ini diguanakan untuk menekan resiko tidak bekembangnya wakaf produktif dan dapat mengurangi rasio terbengkalainya wakaf serta menekan resiko bisnis, bisa dengan meminjamkan wakaf, menjual hak monopoli wakaf dan menyewakan wakaf.

4. Manajemen pemanfaatan yaitu kebebasan dalam bertindak berdasarkan nilai-nilai agama untuk mendapatkan manfaat.

5. Manajemen pelaporan merupakan kegiatan pelaporan dari beberapa kegiatan transaksi suatu perusahaan.

\section{Maqashid Syariah}

Maqashid Syariah merupakan aturanaturan yang telah ditetapkan oleh Allah SWT untuk kemaslahatan umatnya, para ulama klasik seperti Al Syatibi menetapkan tingkatan maqashid syariah menjadi 3 yaitu pertama, maqashid dharuriyat atau disebut kebutuhan primer seperti indikator agama (hifdzu dien), indikator jiwa (hifdzu nafs), indikator keturunan (hifdzu nasl), indikator akal (hifdzu aql) dan indikator harta (hifdzu maal). Kedua, maqashid hajjiyat merupakan kebutuhan sekunder untuk memenuhi kebutuhan manusia dan ketiga, maqashid tahsiniyat atau biasa disebut dengan kebutuhan pelengkap jika tidak terpenuhi tidak berpengaruh terhadap kehidupan manusia (Wulandari, 2017).

\section{METODE PENELITIAN}

\section{Jenis Penelitian}

Penelitian ini menggunakan metode kualitatif. Hal ini karena peneliti menjelaskan dan menganalisis terkait objek yang diteliti. Penelitian kualitatif adalah metode penelitian yang dapat digunakan untuk menganalisis dan memahami makna yang berasal dari masalah-masalah fokus atau fenomana fokus serta kemanusiaan (Nugrahani, 2014). Jenis pendekatan yang digunakan oleh peneliti yaitu studi kasus karena penelitian dilakukan terhadap informan yang bersangkutan seperti nadzir dan pihak penyewa wakaf sawah yang melakukan sewa lahan wakaf sawah.

\section{Teknik Pengumpulan Data}

Teknik pengumpulan data yang digunakan untuk penelitian ini terdiri dari tiga macam yaitu observasi, wawancara dan dokumentasi (Raco, 2018). Pertama observasi, peneliti mengamati terkait aktivitas yang dilakukan oleh pihak informan pada tempat penelitian. Objek yang diamati oleh peneliti adalah place, actor, activity. Peneliti memiliki teknik observasi partisipasi pasif karena dalam penelitian hanya melihat kegiatan sehari-hari pada objek yang diamati tanpa ikut terlibat dalam kegiatan tersebut oleh karena itu peneliti hanya bertindak sebagai pengamat atau observer.

$\begin{array}{rrr}\text { Kedua } & \text { wawancara, dalam } \\ \text { melaksanakan } & \text { wawancara } & \text { peneliti }\end{array}$ menggunakan teknik wawancara terstruktur yang dimana teknik pengumpulan data dengan memberikan pertanyaan ke informan, informan yang dipilih oleh peneliti yaitu nadzir atau pengelola wakaf tanah masjid Jami' Darussalam dan penyewa lahan wakaf berupa tanah sawah. Wawancara dilakukan dengan mendatangi setiap rumah informan pada siang dan malam hari. 
Tabel 1. Daftar Data Informan

\begin{tabular}{clc}
\hline No & \multicolumn{1}{c}{ Nama Penyewa Tanah Wakaf Sawah } & Kedudukan \\
\hline 1 & Bapak Gondo & Nadzir atau pengelola wakaf \\
\hline 2 & Bapak Mintik & Melakukan sewa \\
\hline 3 & Bapak Edi & Melakukan sewa \\
\hline 4 & Bapak Sukar & Melakukan sewa \\
\hline 5 & Bapak Ngadino & Melakukan sewa \\
\hline 6 & Bapak Widji & Melakukan sewa \\
\hline 7 & Bapak Jasmadi & Melakukan sewa \\
\hline 8 & Bapak Sukar & Melakukan sewa \\
\hline
\end{tabular}

Sumber: Data Olahan (2021)

Ketiga dokumentasi, teknik pengumpulam dokumentasi ini merupakan salah satu pelengkap dari penggunaan metode pada observasi dan wawancara berupa foto sebagai bukti peneliti melakukan wawancara dengan informan, transkrip rekaman suara peneliti dengan informan saat melakukan wawancara untuk mendapatkan data yang dibutuhkan peneliti dalam manajemen pengelolaan wakaf tanah.

\section{Teknik Analisis dan Inteprestasi Data}

Teknik analisis dan interprestasi data yang dipilih yaitu model Miles dan Huberman dengan analisis reduksi data, penyajian data dan penarikan kesimpulan (Shidiq \& Choiri, 2019).

Reduksi data, digunakan untuk ketika data yang didapat terlalu banyak sehingga harus memilah hal-hal yang penting, kemudian hasil reduksi bisa memberikan gambaran permasalahan yang diteliti, reduksi data ini sangat penting karean jika terdapat berbagai sumber yang berbeda dari pihak satu ke pihak yang lain peniliti dapat memilah jawaban yang tepat agar seusai jawaban dua rumusan masalah dalam penelitian.

Penyajian data, bersifat naratif yang berasal dari hasil wawancara peneliti kepada nadzir dan penyewa lahan tanah wakaf, data yang dijelaskan oleh informan data yang bisa digunakan untuk menjawab pertanyaan dari dua rumusan masalah.

Penarikan kesimpulan, merupakan penarikan inti dari keseluruhan data yang telah terkumpul dari penelitian. Dengan demikian, hasil dari penelitian memperoleh kesimpulan atau validasi dari penelitian terkait manajemen pengelolaan wakaf tanah masjid Jami' Darussalam Desa Jatipayak Kecamatan Modo Kabupaten Lamongan untuk meningkatkan perekonomian masyarakat.

\section{Uji Kredibilitas}

Tahap yang digunakan untuk memberikan keyakinan dari hasil penelitian, yang bertujuan untuk memperoleh data valid disebut uji kredibilitas. Teknik dalam menguji kredibilitas pada suatu data yang terdiri dari sumber, teknik dan waktu disebut dengan triangulasi (Nugrahani, 2014).

Triangulasi sumber, sumber data terkait manajemen pengelolaan wakaf tanah didapatkan dari sumber yang berbeda yaitu nadzir atau yang mengelola wakaf dan penyewa lahan wakaf tanah berupa sawah. Sumber yang diberikan disetiap informan menghasilkan pernyataan yang sama jika manajemen wakaf digunakan dalam pengelolaan wakaf tanah yang dimiliki masjid Jami' Darussalam dan dapat meningkatkan perekonomian masyarakat.

Triangulasi teknik, untuk dapat menguji kreadibilitas data yang didapatkan dari informan yaitu nadzir atau pengelola wakaf dan penyewa lahan wakaf tanah berupa sawah dengan menggunakan teknik wawancara terkait manajemen pengelolaan wakaf tanah dan peningkatan perekonomian masyarakat dan diuji kembali saat melakukan observasi di nadzir dan penyewa lahan tanah wakaf masjid Jami' Sidoarjo untuk bisa mendapatkan data yang sama saat wawancara dan dibuktikan saat melakukan observasi.

Triangulasi waktu, pada triangulasi waktu ini peneliti mendapatkan waktu saat narasumber memiliki waktu luang, untuk 
nadzir atau pengelola wakaf dilakukan pada malam hari agar tidak menggangu waktu bekerjanya, sedangkan untuk penyewa tanah wakaf pengambilan data dilakukan pada saat siang dan malam hari karena di pagi hari para informan ke sawah.

\section{HASIL DAN PEMBAHASAN}

\section{Keadaan Sosial Ekonomi dan Potensi Sumber Daya Alam Desa Jatipayak}

Desa Jatipayak merupakan satu pemerintahan yang ada sejak tahun 1901 yang meliputi 4 Dusun, 6 RW dan 23 RT dengan luas wilayah yang pemanfaatannya sebagai sawah setengah tehnis $136 \mathrm{Ha}$, sawah tadah hujan $161 \mathrm{Ha}$, pekarangan 63
Ha dan tegal 8 Ha. Letak wilayah Desa Jatipayak berada di kecamatan Modo kabupaten Lamongan, dengan total jumlah penduduk 2442 jiwa dengan jumlah laki-laki 1237 jiwa dan jumlah perempuan 1205 jiwa pada tahun 2020 .

Perekonomian masyarakat desa Jatipayak saat ini berprofesi sebagai petani, akan tetapi masih ada masalah ketenagakerjaan yaitu banyaknya pemuda yang menginginkan jenis pekerjaan lain sehingga banyak calon pekerja yang mecari kesibukan dibidang lain berikut data jumlah Tenaga kerja Desa Jatipayak Tahun 2020. Adapun grafik mata pencarian penduduk Desa Jatipayak.

Gambar 2. Mata Pencarian Desa Jatipayak

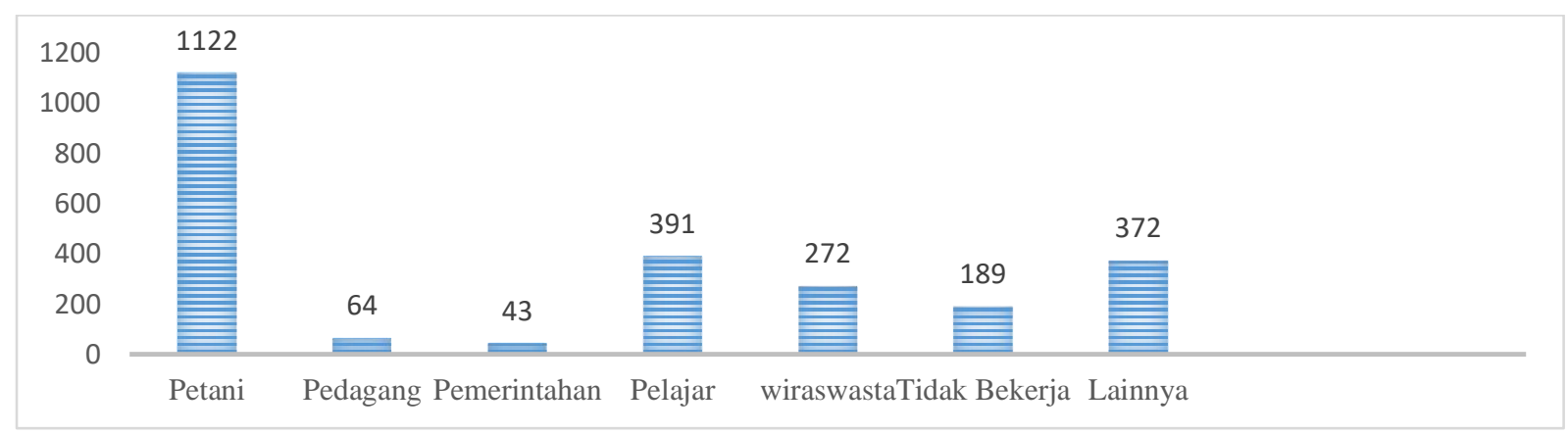

\section{Sumber: Data Olahan (2020)}

Dari grafik di atas menunjukkan bahwa mayoritas pekerjaan masyarakat Desa Jatipayak terbanyak adalah petani, oleh karena itu nadzir sebagai pengelola tanah wakaf yang berbentuk sawah tersebut menyewakan tanah wakaf kepada masyarakat untuk menambah atau memenuhi kebutuhan masyarakat dan menghindari terbengkalainya tanah wakaf sawah masjid di Desa Jatipayak.

\section{Manajemen Pengelolaan Wakaf Tanah Masjid Jami' Darussalam Desa Jatipayak Kecamatan Modo Kabupaten Lamongan}

Manajemen dalam perwakafan sangat penting digunakan dalam mengatur dan mengontrol perkembangan wakaf tidak hanya itu dengan adanya menajemen maka dapat menjaga hubungan antara nadzir, wakif dan masyarakat.

Fungsi dari manajemen sendiri adalah digunakan agar wakaf menjadi produktif dengan nadzir sebagai penanggung jawab akan pengelolaan wakaf tersebut, dalam pengelolaan wakaf produktif melakukan perencanaan, pengorganisasian, pengarahan dan pengawasan, supaya pengelolaan bisa produktif maka nadzir harus memahami prinsip-prinsip manajemen sebagai berikut : 
Gambar 3. Prinsip-Prinsip Manajemen

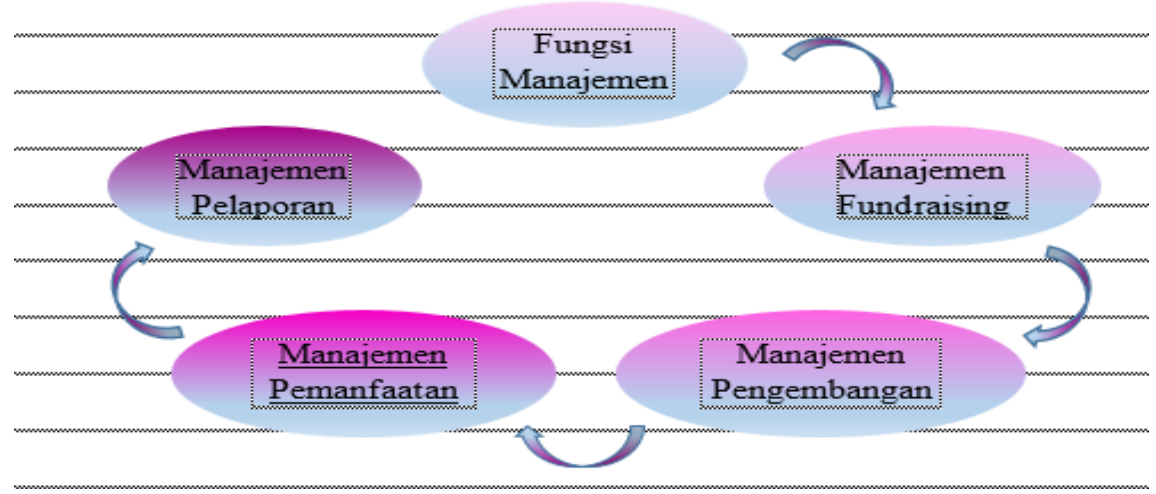

Sumber: Mustofa et al (2020)

Nadzir masjid Jami' Darussalam Desa Jatipayak kecamatan Modo kabupaten Lamongan dalam manajemen pengelolaan wakaf melakukan pengelolaan wakaf produktif supaya dapat berjalan dengan baik dan sesuai ketentuan yang telah ditetapkan agar menghindari terbengkalainya suatu wakaf maka manajemen yang dilaksanakan nadzir masjid Jami' Darussalam Desa Jatipayak kecamatan Modo kabupaten Lamongan menggunakan prinsip-prinsip manajemen pemanfaatan yaitu:

\section{Tahap fungsi manajemen}

Pada tahap fungsi manajemen ini nadzir dalam pengelolaan wakaf tanah yang berupa sawah tersebut melakukan beberapa aspek manajemen yaitu perencanaan, pengorganisasian, pengarahan dan pengawasan.

a. Perencanaan, nadzir hanya menyewakan wakaf tanah yang berupa sawah tersebut kepada masyarakat diutamakan jamaah masjid Jami' Darussalam dengan hasil sewa yang terbatas maka belum dikembangkan kebidang yang lain.

b. Pengorganisasian, nadzir sudah terstruktur dari Pengurus masjid Jami' Darussalam yang ditunjuk langsung oleh Jamaah Masjid Jami' Darussalam.

c. Pengarahan, dalam pengarahan ini difokuskan pada pengarahan pelaksanaan wakaf yang dimana uang hasil dari sewa tersebut diberikan kepada masjid yang digunakan untuk perkembangan masjid tidak hanya masjid yang merasakan manfaat dari tanah sawah wakaf tersebut akan tetapi juga masyarakat yang menyewa tanah sawah wakaf tersebut hanya dengan membayar uang sewa dan keuntungan dari pengelolaan sawah tersebut bisa diambil manfaatatnya oleh penyewa tanpa ada potongan biaya lagi.

d. Pengawasan, pengawasan wakaf dilaksanakan oleh nadzir yang ditunjuk langsung oleh jamaah masjid Jami' Darussalam dalam hal ini Bapak Gondo juga Melakukan pelaporan terhadap segala sesuatu tentang wakaf produktif ke Departemen Agama kabupaten Lamogan.

\section{Manajemen Fundraising}

Nadzir masjid Jami' Darussalam Desa Jatipayak kecamatan Modo kabupaten Lamongan dalam manajemen fundraising melakukan penyusunan strategi dan rencana program kerja dalam wakaf produktif. Perencanaan strategi yang digunakan dalam pengelolaan wakaf dilasanakan dengan terperinci, yaitu dengan menyewakan wakaf tanah tersebut yang berbentuk sawah atau lahan pertanian kepada masyarakat, sedangkan program kerja yang telah direncanakan adalah pembangunan atau mengembangan masjid Jami' Darussalam dengan menggunakan hasil dari sewa tanah sawah wakaf tersebut. 
3. Manajemen Pengembangan

\begin{tabular}{l}
\multicolumn{3}{c}{ Nadzir masjid Jami' Darussalam } \\
Desa Jatipayak Kecamatan Modo \\
Kabupaten Lamongan \\
pengembangan wakaf ini nadzir \\
menggunakan prinsip penghimpun dan \\
menyaluran dana. Pada prinsip
\end{tabular}

penghimpun dana dilakukan penyewaan terhadap lahan sawah tanah wakaf, nadzir memberikan biaya sewa terhadap tanah sawah yang disewakan berdasakan kelas yang telah ditetapkan setiap 2 tahun sekali dengan harga yang berbeda yaitu sebagai berikut :

Tabel 2. Biaya Sewa Tanah Wakaf Sawah Masjid Jami' Darussalam

\begin{tabular}{ccccccc}
\hline No & Keterangan & $\begin{array}{c}\text { Luas Tanah } \\
\left(\mathbf{M}^{\mathbf{2}}\right)\end{array}$ & Tahun & Harga Sewa & Tahun & Harga Sewa \\
\hline 1. & Kelas 1 & 3.480 & $2017-2018$ & 6.000 .000 & $2019-2020$ & 6.000 .000 \\
\hline 2. & Kelas 2 & 2.420 & $2017-2018$ & 3.700 .000 & $2019-2020$ & 4.200 .000 \\
\hline 3. & Kelas 3 & 2.000 & $2017-2018$ & 3.150 .000 & $2019-2020$ & 3.250 .000 \\
\hline 4. & Kelas 4 & 2.000 & $2017-2018$ & 2.300 .000 & $2019-2020$ & 2.600 .000 \\
\hline
\end{tabular}
Sumber: Data Olahan (2020)

4. Manajemen Pemanfaatan

Dalam manajemen pemanfaatan ini masih bisa dikatakan sebagai pemanfaatan yang konsumtif dikarenakan belum meluasnya pengembangan wakafnya hanya digunakan untuk meningkatkan perekonomian masyarakat dan kepentingan masjid tanpa memanfaatkannya lebih meluas di bidang yang lain atau usaha yang lain.

Penyaluran dana yang ditetapkan oleh nadzir yang disepakati oleh masyarakat digunakan untuk kepentingan masjid Jami' Darussalam yang sampai saat ini pada tanggal 11 Mei 2021 sisa uang kas Masjid Jami' Darussalam senilai Rp. 7.747.000. Sedangkan hasil dari pengelolaan sawah itu kembali kemasyarakat itu sendiri untuk meningkatan perekonomian masyarakat.

\section{Manajemen Pelaporan}

Dalam laporan keuangan sebuah refleksi dari beberapa transaksi dalam perusahaan sehingga nadzir wakaf masjid Jami' Darussalam melaporkan keuangannya disetiap pengeluaran dan pemasukannya dilakukan penulisan dan pengecekan secara rutin tidak hanya itu nadzir juga melaporkan wakaf produktif secara rutin ke Departemen Agama Kabupaten Lamongan akan tetapi nadzir masjid Jami' Darussalam belum melakukan pelaporan secara rutin.

\section{Dampak Manajemen Pengelolaan Wakaf Tanah Masjid Jami' Darussalam Desa Jatipayak Kecamatan Modo Kabupaten Lamongan untuk Meningkatkan Perekonomian Mayarakat}

Indikator yang digunakan untuk mengetahui dampak manajemen pengelolaan wakaf tanah masjid pada peningkatan masyarakat Desa Jatipayak menggunakan teori ilmiah yang menjadi rujukan indikator peningkatan perekonomian dengan menggunakan nilai-nilai Islami yaitu indikator maqashid syariah.

Beberapa indikator yang digunakan untuk peningkatan perekonomian masyarakat yaitu indikaor agama (hifdzu din), indikator jiwa (hifdzu nafs), indikator akal (hifdzu aql), indikator keturunan (hifdzu nasl) dan indikator harta (hifdzu mall).

Pertama, peningkatan perekonomian indikator agama, didalam indikator ini penyewa tanah wakaf sawah yang dirasakan adalah dari segi kerohanian, yang dimaksud segi kerohanian adalah para penyewa tanah melakukan amal jariyah meliputi zakat dan sedekah dari perolehan hasil sewa tanah wakaf sawah, manfaat yang didapat tidak hanya di dunia akan tetapi amalan tersebut akan dibawa sampai keakhirat. Pada saat wawancara yang digunakan dalam indikator agama meliputi sedekah dan zakat berikut diagram dampak manajemen pengelolaan wakaf tanah masjid Jami' Darussalam bagi peningkatan perekonomian masyarakat yang 
dirasakan oleh penyewa tanah sawah wakaf di Desa Jatipayak dalam indikator agama.

Gambar 4. Amal Jariyah Zakat

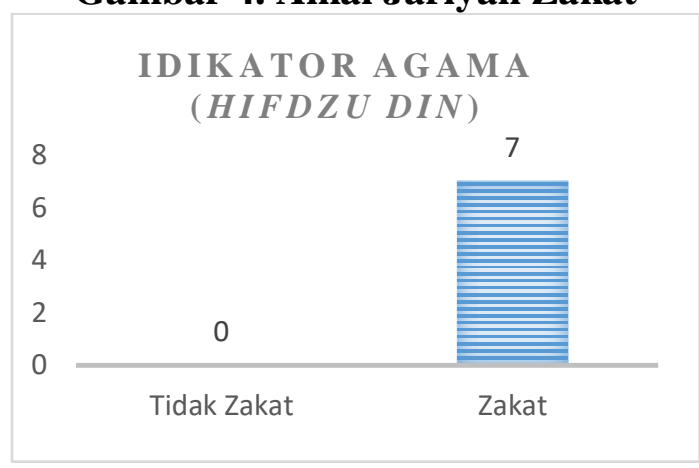

Sumber: Data Olahan (2021)

Gambar 5. Amal Jariyah Sedekah

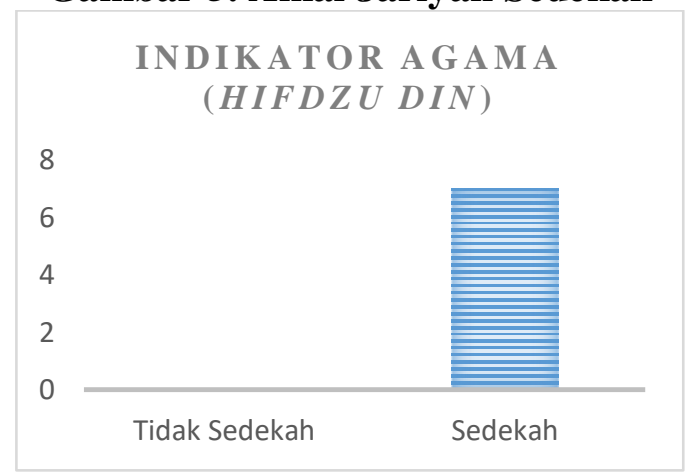

Sumber: Data Olahan (2021)

Pada diagram di atas dapat dilihat bahwa peningkatan perekonomian masyarakat indikator agama dalam melakukan amalan zakat dari 7 orang penyewa semua mampu untuk membayar zakat sehingga tanah wakaf sawah tersebut dapat meningkatkan aspek kerohanian dalam zakat, sama halnya dengan aspek kerohanian dalam sedekah dari 7 orang penyewa dapat meningkatkan amalan sedekah sebagian perolehan hasil dari pengelolaan tanah wakaf tersebut diberikan kepada masjid bisa berupa uang atau gabah.
Kedua, peningkatan perekonomian masyarakat indikator jiwa dapat diukur dari terpenuhinya uang hasil sewa dan hasil panen untuk kebutuhan masyarakat oleh pelaku sewa tanah wakaf masjid Jami' Darussalam Desa Jatipayak. Berikut ini diagram batang dampak menajemen pengelolaan wakaf tanah Masjid Jami' Darussalam untuk peningkatan perekonomian masyarakat penyewa lahan tanah wakaf sawah masjid Jami' Darussalam Desa Jatipayak. 


\section{Gambar 6. Terpenuhi Kesehatan Penyewa Tanah wakaf Masjid}

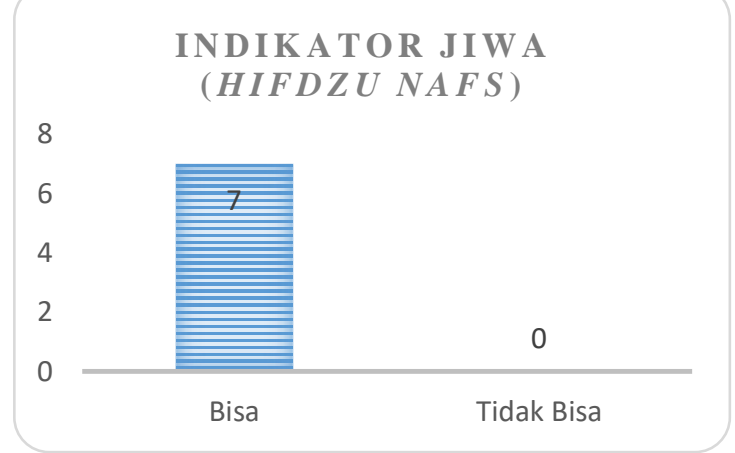

Sumber: Data Olahan (2021)

Dari data diagram batang di atas dapat diketahui bahwa dari 7 orang penyewa tanah wakaf sawah masjid Jami' Darussalam tersebut dapat mencukupi untuk kebutuhan kesehatan seperti untuk membeli obat dan perawatan kesehatan lainnya untuk menunjang kesehatan dengan menjual beberapa hasil dari pengelolaan sewa tanah wakaf sawah tersebut.
Ketiga, peningkatan perekonomian masyarakat indikator akal, pada indikator ini yang dapat dilihat adalah dari peningkatan pengetahuan atau pemahaman penyewa tanah wakaf sawah terhadap pengelolaan sawah atau terkait pertanian. Berikut diagram garis dampak manajemen pengelolaan wakaf tanah masjid Jami' Darussalam untuk peningkatan perekonomian masyarakat Desa Jatipayak.

\section{Gambar 7. Tingkat Pengetahuan dalam Melakukan Sewa}

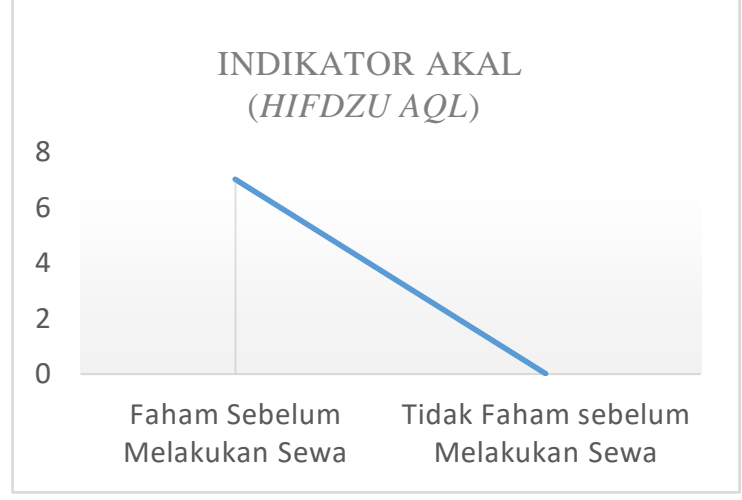

Sumber: Data Olahan (2021)

Dari diagram garis di samping dapat disimpulkan bahwa peningkatan perekoniman masyarakat indikator akal meningkat karena 7 orang penyewa lahan tanah wakaf sawah masjid tersebut sudah memamahi pertanian atau sudah sebagai pekerjaan mereka sebagai seorang petani.

Setelah mereka menyewa lahan lebih dapat memahami tentang cara menyewa lahan pertanian yang sesuai dengan syariah islam yang jujur, terbuka dan saling percaya, cara pengelolaan sawah, cara menanam padi dan tembakau dengan baik dan benar, cara mengatasi hama, cara mengetahui kualiatas tanaman yang bagus 7 orang penyewa tersebut dapat memahami tersebut dengan benar sehingga dapat meningkatkan perekonomian masyarakat pada indikator akal.

Keempat, peningkatan perekonomian pada indikator keturunan, pada indikator ini diukur dari terpenuhinya hasil sewa untuk kepentingan biaya pendidikan anak para penyewa tanah wakaf sawah di Desa Jatipayak. Berikut diagram lingkaran 
dampak manajemen pengelolaan wakaf tanah masjid Jami’ Darussalam Desa Jatipayak.

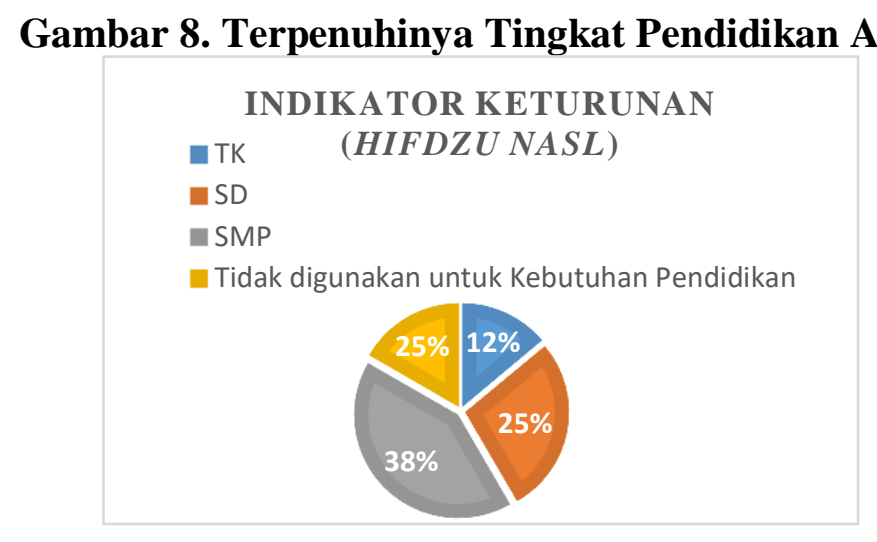

Sumber : Data Olahan (2021)

Pada diagram lingkaran di atas dilihat bahwa hasil dari sewa dapat digunakan anak petani, dari data di atas menunjukan $12 \%$ untuk biaya sekolah TK, 25\% untuk biaya SD, 38\% untuk biaya SMP, 25\% tidak dipergunakan untuk biaya sekolah karena dipergunakan untuk kebutuhan yang lain dan tidak mempunyai anak. Dengan demikian dapat disimpulkan bahwa peningkatan perekonomian dari segi keturunan dapat terpenuhi dengan adanya hasil sewa tanah waqaf masjid.

Kelima, peningkatan perekonomian masyarakat pada indikator harta dapat dilihat dari peningkatan penghasilan penghasilan penyewa dengan cara melihat perolehan penghasilan sewa dari tanah wakaf sawah masjid Jami' Darusalam Desa Jatipayak. Berikut diagram batang pada peningkatan perekonomian masyarakat dalam indikator harta.

\section{Gambar 9. Peningkatan Penghasilan Penyewa}

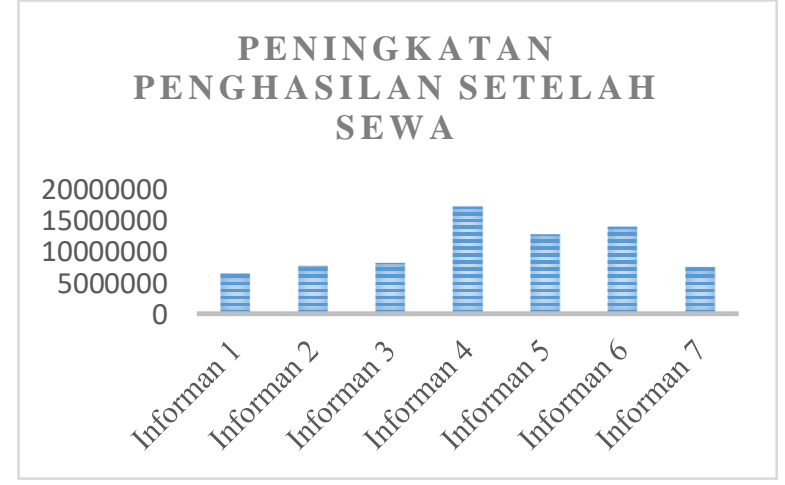

Sumber: Data Olahan (2021)

Dari diagram batang di atas dapat dilihat bahwa hasil dari perolehan sewa dapat meningkatkan perekonomian masyarakat karena dengan jumlah perolehan pengelolaan tanah wakaf sawah tersebut dapat dipergunakan untuk memenuhi kebutuhan yang mereka inginkan.

\section{KESIMPULAN}

Berdasarkan hasil wawancara manajemen pengelolaan wakaf tanah masjid Jami' Darusalam Desa Jatipayak diketahui belum terlaksanakan dengan baik dan struktural karena bersifat konsumtif dan belum mengalami perluasan perkembangan investasi pada pengelolaannya, serta masih 
terdapat perbedaan dari beberapa informan antara nadzir dengan penyewa tanah wakaf. Dalam menjawab pertanyaan tentang biaya sewa dan nama penyewa dikarenakan nadzir tidak mencatat secara detail hal-hal yang penting dari pelaksanaan perjanjian sewa tanah wakaf. Sedangkan hasil wawancara bagi dampak manajemen pengelolaan tanah wakaf masjid dapat dilihat dari peningkatan perekonomian masyarakat Desa Jatipayak. Diketahui bahwa indikator agama, indikator jiwa, indikator akal, indikator keturunan, dan indikator harta dapat memenuhi peningkatan perekonomian dan dapat memenuhi kebutuhan penyewa.

\section{DAFTAR PUSTAKA}

Assegaf, M. \& Mursyid, K. 2020. Pelaksanaan Wakaf Produktif di Bank Wakaf Mikro Syariah Denanyar Jombang. Manajement of Zakah and Waqaf, 1(1), p. 66-78.

Darwanto. 2012. Wakaf sebagai Alternatif Pendanaan Penguatan Ekonomi Masyarakat Indonesia. Jurnal Ilmu Manajemen Dan Akuntansi Terapan, 3(1), p. 1-14.

Fahri, M. B., \& Zaki, I. 2018. Strategi Manajemen Pengelolaan Wakaf Produktif di Pesantren Yayasan Arwaniyyah Kudus. Jurnal Ekonomi Syariah Teori Dan Terapan, 5(7), p. 699-712.

Hasan, S. \& Rajafi, A. 2018. Pengelolaan Tanah Wakaf di Kota Manado. Journal of Islam and Plurality, 3(2), p. 281-300.

Hasanah, I. 2020. Menelaah Wakaf Produktif Atas Solusi Masalah Umat Berdasarkan PSAK 112. Jurnal Tabarru': Islamic Banking and Finance, 3(2), p. 313-325.

Huda, M. \& Fauzi, A. 2019. Sistem Pegelolaan Wakaf Masjid Produktif Perspektif Hukum Islam (Studi Kasus di Masjid Islamiyah Nalumsari Jepara). Jurnal At-Tamwil, 1(2), p. 27-46.
Huda, N. Rini, N. Mardoni, Y. Anggraini, D. \& Hudori, K. 2018. Manajemen Pengelolaan Wakaf di Indonesia Timur. EKUITAS (Jurnal Ekonomi Dan Keuangan), 20(1), p. 1-17.

Komarudin, T. Damiri, A. \& Jalaludin, J. 2020. Pengelolaan Wakaf Produktif Tanah Sawah di Yayasan Islam Pondok Pesantren Miftahul Jannah Jatibaru Kecamatan Jatisari Karawang. EKSISBANK : Ekonomi Syariah Dan Bisnis Perbankan, 4(1), p. 1-10.

Latifah, F. N. E, M., Rismadayanti, C. E. Alamsyah, R. S., Mukaromah, L. \& $\mathrm{Sa}, \mathrm{P}$. 2021. Implementasi Wakaf Produktif dan Wakaf Tunai Di Indonesia. Izdihar : Jurnal Ekonomi Syariah, 1(1), p. 92-116.

Masruchin. 2019. Penerapan Corporate Social Responsibility Dalam Pengelolaan Wakaf Produktif. Istithmar, 3(1), p. 61-83.

Muqorobin, Ahmad., \& Agustiyani, Mahmudah. 2017. Optimalisasi Sektor Pertanian melalui Penerapan Wakaf Berkelanjutan. PROCEEDINGS of Annual Conference for Muslim Scholars (AnCoMS), (seri 1), p.10-16.

Mustofa, A. Suryanto, T. Ghofur, R. A. Islam, U. Raden, N. \& Lampung, I. 2020. Implementasi Manajemen Wakaf Pada Lembaga Sosial Keagamaan. Jurnal Perspektif Ekonomi Darussalam, 6(2), p. 223235.

Nugrahani, F. 2014. Metode Penelitian Kualitatif Dalam Penelitian Pendidian Bahasa. Cakra Book. Solo.

Nurma. 2013. Investasi Dana Wakaf. Jurnal Khatulistiwa-Journal of Islamic Studies, 3(1), p. 11-18.

Oktafia, R., Sn, N. Q., \& Yani, M. 2020. Model Pengelolaan Dana Sosial Pupas Universitas Airlangga dalam Meningkatkan Produktifitas Mustahik 
di Jawa Timur. Jurnal Imara, 4(3), p. 148-158.

Raco, J. 2018. Metode Penelitian Kualitatif: Jenis, Karakteristik Dan Keunggulannya. PT. Grasindo. Jakarta.

Rahman, Fawait Syaiful. 2019. Manajemen Wakaf Produktif Dan Kontribusinya Terhadap Penguatan Pondasi Ekonomi Masyarakat. Tafaqquh: Jurnal Penelitian Dan Kajian Keislaman, 7(2), p. 17-34.

Rahman, I. \& Widiastuti, T. 2020. Model Pengelolaan Wakaf Produktif Sektor Pertanian Untuk Meningkatkan Kesejahteraan Petani (Studi Kasus Pimpinan Ranting Muhammadiyah Penatarsewu Sidoarjo). Jurnal Ekonomi Syariah Teori Dan Terapan. 7(3), p. 486-498.

Rozalinda, R. 2012. Efek Ganda Pengelolaan Wakaf Uang. MIQOT : Jurnal IlmuIlmu Keislaman, 35(2), p. 314-330.

Shidiq, U., \& Choiri, M. 2019. Metode Penelitian Kualitatif di Bidang Pendidikan. CV. Nata Karya. Ponorogo.

Wulandari, D. N. Santoso, B. \& Athar, H. S. 2017. Etika Bisnis E-Commerce Berdasarkan Maqashid Syariah Pada Marketplace Bukalapak.Com. Jmm Unram-Master of Management Journal, 6(1), p. 1-13. 